\title{
Description of Fiscal Legislation and Changes in Years in Albania
}

\author{
MSc. Edvin Xhango \\ e_xhango@yahoo.com
}

\begin{abstract}
The development of the appropriate tax law was very important but also very difficult for countries coming from a centrally planned economy. In this paper, the author discusses the framework of tax law drafted from 1993 until 2014. In the study we present as the legislation has changed in these years and have influenced legal solutions to improve business data; thus affecting the development of the economy. We have identified legal definitions that provide the right solutions for business as well as for the economy of the state. We have selected the popular items and the articles that encourage business to develop informal economy. For this study is the ratio of Value Added Tax and Income tax on gross domestic product, which from 1998 until 2014 is almost the same. Noting that Albania is the country with the size of informal economy $34-47 \%$, the result is about the legal framework of deficiencies. Given the above results, we have studying business interests to develop the informal economy. For this aid comes in the study of Busato and Chiarini, 2004, by which it can be determined the cost of product development business to the informal economy. Calculations showed that the cost of the development of the informal sector is much lower than the fiscal burden. Based on the results we conclude that the legal framework needed to improved in terms of avoidance of tax evasion opportunities as recognition of all invoiced costs, increasing penalties for not declaring the income and improve the work of the tax administration.
\end{abstract}

Keywords: tax law, VAT, profit tax, penalty

\section{INTRODUCTION}

The design and development of a good and effective Tax Law (System) is a challenge for every government in every country of the world because this law (system) should promote the economic development and the general welfare. This task becomes even more difficult in countries that have had a centralized economy such as Albania. In this article, we handle evolution of the tax law for the period from 1993 to 2015.

This study brings some main points of tax law reform in Albania with the aim to analyze its strengths and weaknesses and requires the attention of economists and policy makers in the country on the improvement of the legal framework to avoid tax evasion and distortion of the market through it.

The research questions of this study are:

How it was develop in a fiscal legislation in Albania?

What has changed in the tax law during the period from 1993 to 2015 ?

What way economists and policy makers need to address the issue of tax evasion in Albania in? 


\section{METHODOLOGY}

This study has used the qualitative research method based on literature reviews that serve as a scientific field by providing a much-needed bridge between the vast and scattered assortment of articles on a topic and the reader who does not have time or resources to track them down.

The study is base on a review of the tax law framework developed in the early 90s in Albania. The study has taken all the laws that are part of the fiscal package and reviewed changes made over the years. In each of the laws, we have selected beneficiaries and consequences for violators of norms provided. In all cases, it was considerer their clarity and consistency with existing legislation.

To evaluate the interest of business to develop the informal sector we have used the equation developed by Francesco Bruno and Chiarini Bussato (April 2003). The function is:

$Y^{i}{ }_{D t}=\left(1-T_{t}^{t}\right)^{*} y^{i}{ }_{m t}+\left(1-s T_{t}^{f}\right)^{*} y^{i} u t$

$E(y i t / t)=\left(1-T_{t}^{t}\right)^{*} y^{i} m t+\left(1-p s T_{t}^{t}\right)^{*} y^{i} u t$

$s$ - The additional taxes that a business pays in case of capture by the non- formal business tax.

$\mathrm{Tft}$ - represents business tax

$p$ - The probability that a firm will audited at the time $t$

$\mathrm{i}-$ Business

$m$ - Formal sector

$u$ - Informal sector

$y$ - Product

\section{Procedure}

\section{Criteria for selection of laws}

In this study, we have selected the laws based on:

Interesting for the subject,

Importance aspect in the field

The author has paid significant attention to these ethical principles:

Transparency

Ensuring accuracy

Reporting of results 


\section{RESULTS}

In the Law for Capital Gains Tax (CGT), we find that entities are subject of it. The tax rate is determined in $30 \%$; the fiscal period for which the tax was calculated - yearly; were determined the businesses that were exempt from income tax and businesses that will have other norms such as hydrocarbons business (tax for which will be $50 \%$ ); were stated that the losses from economic activity derived by deducting from profits of three years ad; at the beginning of the year must be declared the profit for the coming year, and for the quarter and how it will be realized. In this law, we find and the sanctions for the violators.

In the Law "On documenting and accounting for taxes", are define the main obligations and the basic rules that must be followed by the entity associated with documenting and accounting for tax. The law stipulates that any purchase or service provision tableware allocated to a professional activity be subject to invoicing. In the law are described in detail the constituent elements of the bill. Besides tax bill described the document as a tax receipt to be issue by entities for the sale of goods or services to the public. In addition, the law has determined penalties for cases where entities are not equipped with tax casings; do not issue tax vouchers or other violations.

In the Law "On turnover tax" are defined entities, which are subject to this tax as well as goods, products, or devices that will not be subject to this tax. The tax rate is $20 \%$ but paid only once by the manufacturer or importer. In addition, the law has determined the manner of collection and payment of this tax in the budget, as well as penalties for violations.

In January 1994 was adopted the Law "On tax on personal income" in which are defined entities that are subject to this tax and those who are excluded, and his scale ranges from 10-25\% depending on income. In addition, it has determined penalties for cases where there are deviations from the implementation of this law.

In 1995, it was adopted the law "On Value Added Tax" by repeal the law "On turnover tax". The object of this law is the establishment of value added tax. The law defined the persons who are subject of this tax and those that are exempt from it. The law defined the elements of economic activity and ways of performing them with law. In chapter four of his given "value of taxable and tax rate," according to its taxable value is the total amount paid for the supply, except when this law otherwise stated, also the taxable value of supply also included tariffs, taxes, taxes and duties payable. The law stipulates that if the payment reduction that we will have both supply and reduction of taxable value, (Article 29). Article 36 of the law determined that the bill is obliged to issue every person who makes supplies to the person who receives supply. According to the law, the bill should contain the name; address; tax number of the supplier; a description of each type of goods or service; the quantity of goods or service; the price for each type of goods and service, including reductions respective percentage of VAT amount payable to any goods and services; total VAT payable; and the date on which the invoice is issued. Also in the law defined the obligation of tax subjects to provide certain information to the tax authorities, the time for payment of VAT, the right of the organs Tax to perform inspections, penalties for giving incorrect information and in cases when not settled in time liabilities.

In 1998, laws on income tax and tax on personal income was replacing to the law on income tax. This law was positive that the tax burden was sitting in $10 \%$ tax on the profit made by the business units, but on the other part of the expenditure made by business are not recognized by the law. Thus profit to be taxed was great that real to create business profit. However, not recognizing a portion of the costs makes disinterested that these expenses must documented with receipts tax what is in the tax help.

The Law "On income tax", 1998, regulates relationships that occur in the field of personal income tax, profit tax and withholding tax on income. The first part of the law gives the definitions that were use in it. In the second part are treated relations of the personal income tax that include the definitions of taxable income and exempt income The law defined the individual annual statement of income. In the third part are defined the incomes tax rules. In it are defined persons who were subject of profit tax as well as entities that are excluding from this tax. The law also addressed the annual measures fixe asset depreciation and method of calculation, etc.

After numerous changes to the laws mentions above, in 2014 was approved the new law "On value added tax". The new law is more complete than the previous one. According to the new law the "VAT is a tax of general consumption of goods 
and services, proportional on their price, which is charged at every stage of production and distribution process without tax price". VAT is applies as a percentage tax on the price of goods, services and falls due to be paid after deduction of VAT that it rests directly elements of the cost of goods and services. According to the law, we have taxable persons and persons who are not taxable; non-profit organizations that are have payments derived from membership fees, funding or grants, non -profit organizations that have obtained donations for their activities.

The Law "On value added tax" of 1995, reduced tax rate to $12.5 \%$ from $20 \%$ that was before. A measure like this would facilitate businesses that offer products on the market, but not other businesses that have to transfer their products to the consumer. In addition, the distribution of VAT requires a highly professional administration to avoid tax evasion that businesses can do. Another shortcoming was the control of information provided by the business that was missing. In that time, we do not have the computerization of the system and unique elements of the bill. Changes in 1997, by means of which the tax rate for the tax surplus to add rose $20 \%$, as well as changes made by the new law adopted in 2014 and grow even more fiscal burden. Therefore, in case we decrease the value of the invoice, or loss, destruction or theft of it, the taxable value does not change. This means that we have an additional cost that for the business is wastage. Also in the law as we have seen cases that planned for various expenses, their VAT was not deducting. A procedure like this, often encourages business not take invoice for product that cost less. The positive fact in this law was that the bills contained the serial number that makes possible the combination of business data for purchases and sales in one another. This it was possible through computerization of the tax system that has improved a lot the declaration system of small business. In this way, we have fewer cases of abuses from small business and evidences that these legal changes have not remain only on paper but they are part of daily work.

In the tables below were presented GDP changes over the years; the value added tax to GDP; and profit tax to GDP.

\begin{tabular}{|l|l|l|l|l|l|l|l|l|l|l|l|}
\hline & 1993 & 1994 & 1995 & 1996 & 1997 & 1998 & 1999 & 2000 & 2001 & 2002 & 2003 \\
\hline GDP (in trilion eur) & 9.6 & 9.4 & 8.9 & 9.1 & -10. & 12.7 & 10.1 & 7.3 & 7.2 & 3.4 & 6 \\
\hline Turnover tax/VAT & 3.6 & 2.3 & 2.2 & 2.9 & 4.9 & 7 & 6.3 & 7.2 & 7 & 7.3 & 7.3 \\
\hline Profit tax & 2.8 & 1.3 & 1.0 & 1.1 & 0.7 & 1 & 1.3 & 1.5 & 1.7 & 1.6 & 1.8 \\
\hline
\end{tabular}

\begin{tabular}{|l|l|l|l|l|l|l|l|l|l|l|l|}
\hline & 2004 & 2005 & 2006 & 2007 & 2008 & 2009 & 2010 & 2011 & 2012 & 2013 & 2014 \\
\hline GDP (in trilion eur) & 5.9 & 5.8 & 5.4 & 6.0 & 6.1 & 3.3 & 3.5 & 3 & 0.5 & 1.3 & 2.5 \\
\hline VAT (percentage & 7.4 & 7.8 & 8.3 & 9 & 10 & 9.6 & 9.3 & 9.3 & 8.8 & 8.0 & 8.3 \\
\hline Profit tax & 2.1 & \multicolumn{4}{|c|}{ No data } & 1.5 & 1.4 & 1.5 & 1.2 & 1.3 & 1.3 \\
\hline
\end{tabular}




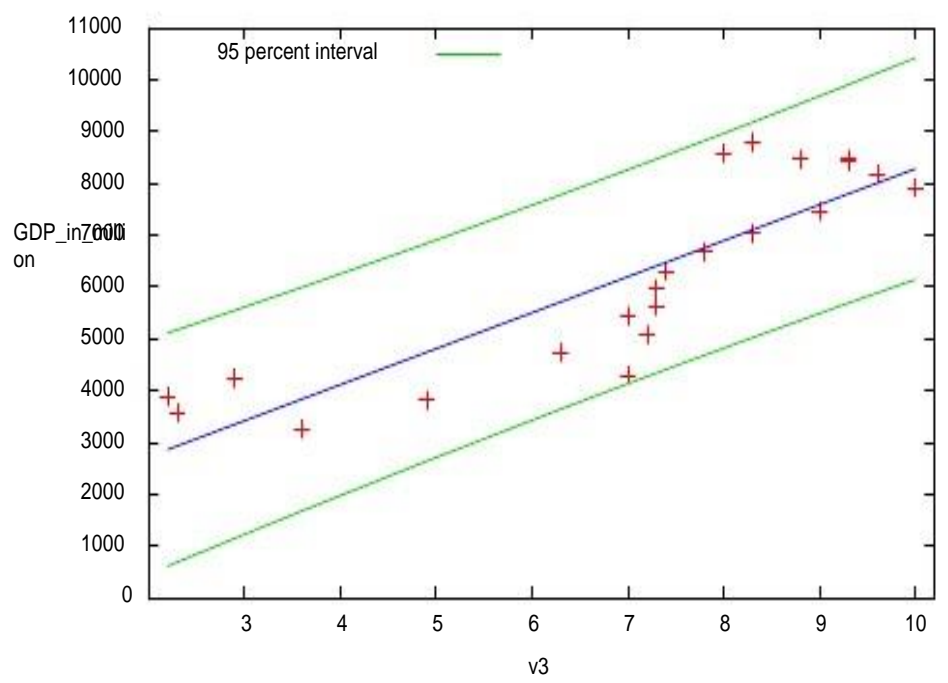

As seen from the table and graph, the rate of growing of GDP from 1993 until 2008, was mainly by 6-9 \%; while from 2009 to 2014 it was 1. 5-3. $5 \%$. Tax percentage against GDP is more or less the same, which shows that legal changes have not affected the reduction of evasion and the shadow economy.

\section{Evaluations conducted on the level of evasion in Albania}

During these 20 years lot of efforts have happened through legal changes to combat and reduce evasion in Albania. Based on different assessments, tax measures ranges from 30-50\%. Nevertheless, naturally the question arises to what extent businesses have to perform tax benefit and where shortages are occurring phenomenon that distorts the market. We must first determine why the business is interested to avoid disclosure of sales. The lack of opportunity to avoid the disclosure of sales to the final consumer makes even supplies to declared, because it is obliged to justify sales and the stocks that are available. However, to evaluate the interest of business to develop the informal sector helps equation developed by Francesco Bruno and Chiarini Bussato (April 2003). The function is:

$Y_{D t}^{i}=\left(1-T_{t}\right)^{*} y_{m t}^{i}+\left(1-S T_{t}\right)^{*} y^{i} u t$

$E(y i t / t)=\left(1-T_{t}\right)^{*} y^{i} m t+\left(1-p s T_{t}\right)^{*} y^{i} u t$

Formula derived from informal business that has an interest to develop when (1-sTft)>0 and the opportunity to be discovered in this case is $(p)$ we can write which will be the total product.

The fiscal burden in Albania is estimate to be about $30 \%$. For the probability of control tax equal to one will have to $s=3$. 3 , since under Albanian law $s \geq$ than 2 results should not be less than 3 , which shows that the business has an interest to develop this sector of economy. In the absence of statistics by the Directorate General of Taxation for the number of checks carried out for these violations, we have used empirical data on the number of tax inspectors and the average time for completion of an audit. In one year, DGT have conducted 4000 audits. It should be note that controls almost totally developed in businesses with legal status "limited liability Company". So the probability for identifying deviations for a business is number of controls/number of business $\rightarrow p=4000 / 22027=18 \%$. Consequently, it turns out that (1-psTft) $>0$, and is approximately $10 \%$, which shows that informal business can be develop with minimal tax cost. This is due to a lower a tax audit after audit turns out that a business after more than five years, but no more punitive measures to curb this way of working. 


\section{CONCSLUSION}

The main shortcoming of these laws developed in the early '90s was that they were shattered. In these conditions, they leave the possibility of unregulated economic transactions. The legislations do not regulate how economic transactions should that are unjustified by invoice should calculate the depreciation of assets. Tax burden it was higher compared to the economic power of the Albanian entrepreneurs and economic might to Albanian customers. So over 30\% income tax, while $20 \%$ turnover tax paid only the ease here from only one manufacturer or supplier who imported. An exposed tax so high interlaced with incomplete documentation and manage newly formed fiscal inexperienced create business all the reasons to develop informal economy. The positive part on the law "On the turnover tax" was that the tax paid only once, which made it easier tax administers. This is very important if we consider the fact that our administration has new employees, without experience in fiscal matters. Subsequent improvements, somewhat incomplete; but only in the legal framework that are associated with partial technological improvements in information processing and without enforcing a change in fiscal load doesn't change the business tax situation in Albania.

Taxable person should be provided for the issuance of invoice by him or by purchasing the trailer or in his name and on his behalf by third parties for any supply or service performed against one another taxable person or a legal person nonassessable also for any payments made before the supply of goods is carried out before the end of the supply or service. The invoice is issued when the supply of goods or services. The invoice contains the date of invoice; a serial number that identifies the bill uniquely; TIN of suppliers; TIN of buyers name and full address of the seller and buyers; description of goods and services, quantity, price per unit without VAT for each type of goods or services; the value of tax applied or excluded, the rate of VAT applied, the amount of VAT payable, the total value of VAT

\section{REFERENCES}

i. de Graaf (2013) 'International tax policy needed to counterbalance the 'excessive' behaviour of multinationals', EC Tax Review, 2013/2, p. 106

[2] Buchanan, J. (1980). The Power to Tax: Analytical Foundations of a Fiscal Constitution. The Collected Works of James M. Buchanan.

[3] Daniel J. Mitchell, Albania Joins the Flat Tax Club. Cato institute, April, 2008

[4] R. T. Kurdle (2014), 'The OECD and international tax regime: persistence pays off', Journal of comparative policy analysis: research policies Taxation trends in the European Union, Eurostat, June 2014

[5] Ridley, D. (2008): The literature review - a step-by-step guide for students. Sage Publications, London.

[6] Rust and C. Micheau (2013) 'State aid and tax law', Wolters and Kluwer (ISBN 978-90-411- 4557-1)

[7] Sato,M. (2003). Tax competition, rent-seeking and fiscal decentralization. European Economic Review, 47, 1940.

[8] Wilson, John D. (1999). Theories of Tax Competition. National Tax Journal, 52, 269-304 